\title{
Acute Diabetic Ketoacidosis in Children: Role of the Stress Hormones
}

\author{
MARGARET H. MACGILLIVRAY, ${ }^{(58)}$ ERIKA BRUCK, AND MARY L. VOORHESS \\ Department of Pediatrics, School of Medicine, State University of New York at Buffalo, and The Children's Hospital \\ of Buffalo, Buffalo, New York, USA
}

\begin{abstract}
Summary
Twenty-five cases of acute ketoacidosis, occurring in insulintreated diabetic children in previous good health, were studied close to the onset of iliness and throughout the first $24 \mathrm{hr}$ of therapy. In most patients, symptoms of illness and ketonuria had been present for less than 12 hr; in 9 subjects, they had been present for less than $4 \mathrm{hr}$. Initial plasma glucose concentrations ranged from 252 to $849 \mathrm{mg} / \mathrm{dl}$. The first pH values in 21 cases were less than 7.27 , and in the remaining 4 studies, the $\mathrm{CO}_{2}$ was less than $14 \mathrm{mEq} /$ liter. Identifiable sources of stress, such as infections or emotional arousal, preceded the development of ketoacidosis in 20 cases.

Serial measurements were made of plasma glucocorticoid, growth hormone, and glucagon concentrations as well as urinary excretion of epinephrine and norepinephrine to assess the role of these hormones in acute ketoacidosis and to evaluate their relationship to the abnormalities in glucose and electrolyte homeostasis. Excessive urinary excretion of epinephrine was a frequent and striking phenomenon. Output was greater than 4 S.D. above the mean in 20 of 23 cases in the first 2 hr of the study. In 15 cases, the values fell into the normal range by approximately $14.5 \mathrm{hr}$, but in seven patients, epinephrine overproduction persisted for the entire study. Cortisol hypersecretion was present in 24 of 25 patients and persisted for 6 to $8 \mathrm{hr}$ or longer before gradually subsiding. Initial growth hormone concentrations were elevated in seven patients $(20 \mathrm{ng} / \mathrm{ml}$ or above), but the highest values (20 to $160 \mathrm{ng} / \mathrm{ml}$ ) were observed after insulin administration. At the outset, plasma glucagon concentrations were less than $200 \mathrm{pg} / \mathrm{ml}$ in 11 patients; in 11 others, it ranged between 250 and $1250 \mathrm{pg}$ / $\mathrm{ml}$. The elevated values usually were transient. Of 22 cases in whom all five hormones were measured at the start of the study, 21 exhibited increased production of at least three of the stress hormones.
\end{abstract}

We conclude that some diabetic children who have received their usual dose of insulin develop hyperglycemia, dehydration, and acidosis within a few $\mathrm{hr}$ of experiencing stress because large amounts of counterregulatory hormones, especially catecholamines and cortisol, are released.

\section{Speculation}

Acute onset of ketoacidosis in previously healthy insulin-treated diabetic children occurs because their daily dose of insulin is insufficient to offset the effects of the counterregulatory hormones produced in response to stress (catecholamines, cortisol, glucagon, and growth hormone). Hyperglycemia, dehydration, and acidosis result from the glycogenolytic, lipolytic, and ketogenic action of the stress hormones.

Acute ketoacidosis may develop within a few $\mathrm{hr}$ in diabetic children who have been in previous good health and free of ketonuria. These crises appear to be precipitated by infection, emotional arousal or other forms of stress. Often, the children have received their usual daily dose of insulin. Thus, absolute insulin deficiency can be excluded in these cases. It is likely that an acute release of "stress hormones" precipitates the decompensation in these diabetic children because their daily dose of insulin is insufficient to offset the profound effects of the counterregulatory hormones on carbohydrate and lipid homeostasis.

Previous observers of this phenomenon have speculated about the role of one or more of the stress hormones in ketoacidosis ( 1 , $18,36,47,48,50$ ), but none have included simultaneous serial measurements of all the major counterregulatory hormones except Waldhausl et al. (53) who studied six insulin-deficient diabetic patients during rehydration. Thus, the frequency, severity, and complexity of the hormonal derangements have not been thoroughly documented.

This is the first study of a large group of young diabetics wherein all of the major stress hormones have been measured close to the onset of illness and every hour during the subsequent $24 \mathrm{hr}$ of therapy. Plasma levels of glucocorticoid, growth hormone, glucagon, and urinary excretion of epinephrine and norepinephrine were measured serially in 25 studies. The interaction between these hormones and the changes in glucose and electrolyte homeostasis were determined to evaluate the contribution of these factors to acute diabetic ketoacidosis.

\section{MATERIALS AND METHODS}

\section{PATIENT SELECTION}

Patients were selected for the study if they had ketonuria and symptoms of illness for less than $24 \mathrm{hr}$. Other criteria included clinical signs of dehydration, acetone odor of the breath, and a positive test for "acetone" in serum diluted four-fold or higher. In 21 cases, the initial pH was less than 7.27 (range 6.96 to 7.27); in the remaining four studies, the $\mathrm{CO}_{2}$ was less than $14 \mathrm{mEq} /$ liter, and the $\mathrm{pH}$ was less than 7.37. The anion deficit ranged from 14 to $38 \mathrm{mEq} /$ liter with a mean of $24.3 \mathrm{mEq} /$ liter. All the patients had received insulin regularly and had had satisfactory control in the recent past as judged by two to four daily urine tests for sugar and acetone.

Written consent of parents and of older patients was obtained for all the studies.

\section{STUDY PROTOCOL}

As soon as the patients arrived in the Emergency Room, a sample of arterial blood was obtained for measurement of glucose, acetone, $\mathrm{pH}, \mathrm{CO}_{2}$, and electrolytes. The patients were asked to void completely, and the time was recorded. If the precise time of the previous urination was known, this specimen was saved for catecholamine analysis. As soon as it was ascertained that the criteria for the study were fulfilled, the patients were transferred to the Clinical Research Center, usually within one hr of arrival. 
COLLECTION OF SPECIMENS

Every $\mathrm{hr}$, for a total of $24 \mathrm{hr}, 1.5$ to $2 \mathrm{ml}$ of venous blood was obtained via an indwelling heparinized infusion needle for determination of glucose, growth hormone, corticoid, and glucagon. An additional $3 \mathrm{ml}$ was taken at $0,4,8,12,16$, and $24 \mathrm{hr}$ for acidbase studies, electrolytes, and urea nitrogen.

Urine was collected quantitatively every $\mathrm{hr}$ for the first $8 \mathrm{hr}$ and every $2 \mathrm{hr}$ thereafter. If the patients were unable to void spontaneously, an indwelling Foley catheter was used. The timed urine specimens were analyzed quantitatively for glucose and electrolytes and qualitatively for ketones. A portion of every specimen was acidified immediately to a $\mathrm{pH}$ of less than 3 with $\mathrm{HCl}$ and frozen for later measurement of epinephrine and norepinephrine.

\section{THERAPY}

Every patient was cared for by one of a group of pediatric residents who were members of the study team. ${ }^{1}$

Fluid therapy was as follows. During the first hr in the Clinical Research Center, balanced hydrating solution ${ }^{2}$ was administered intravenously at a rate of $400 \mathrm{ml} / \mathrm{M}^{2}$. For the next $8 \mathrm{hr}, 5 \%$ glucose in electrolyte solution ${ }^{3}$ was infused at a rate of $250 \mathrm{ml} / \mathrm{M}^{2} / \mathrm{hr}$. In the remaining hours of the study, $10 \%$ glucose in electrolyte solution ${ }^{4}$ was given intravenously at a rate of $125 \mathrm{ml} / \mathrm{M}^{2} / \mathrm{hr}$.

Insulin therapy was initiated after baseline blood specimens had been obtained and after the infusion had been established. In 15 instances, one or two glucose measurements were made, and insulin was administered approximately one hr after the onset of the study. In the remaining cases $(11-14,17,20,24-27)$, insulin was not administered until 2 to $3 \mathrm{hr}$ after initiation of parenteral fluid therapy because a spontaneous fall of blood glucose had been observed in several previous patients before insulin administration. This method of treatment was chosen to determine whether fluid therapy and general care would suffice to initiate recovery in these patients who were not insulin deficient.

In the first 16 studies, the initial insulin dose for the severely ill patients consisted of 1 or 2 units of regular insulin per kg.; onehalf of the dose was given intravenously, and the remainder was given subcutaneously. In the moderately ill children, the dose was 1 unit $/ \mathrm{kg}$. Subsequent insulin therapy was given on the basis of the clinical and biochemical progress of the patient. This treatment regimen was termed the "high dose" method.

In the last nine studies, the initial dose was 10 units of regular insulin per $\mathbf{M}^{2}$ of body surface administered intramuscularly. This dose was repeated every $\mathrm{hr}$ until the concentration of blood glucose was below $250 \mathrm{mg} / \mathrm{dl}$ (or plasma glucose below $300 \mathrm{mg}$ / di). Thereafter, one-half this dose was given at appropriate intervals to maintain the glucose level below $250 \mathrm{mg} / \mathrm{dl}$. This latter regimen was termed the "low dose" method.

Vital signs, including blood pressure, were recorded every hr.

\section{ANALYTIC METHODS}

Glucose concentration was measured in a protein-free filtrate of whole blood with a glucose oxidase method (54). Plasma growth hormone was measured by double antibody radioimmunoassay technique $(21,40)$. Plasma corticoid was determined by the competitive protein binding method of Murphy (32). Antiglucagon antiserum (30K), purchased form Dr. R. Unger, was used to assay plasma glucagon according to the method of Faloona and Unger (15), except that double antibody precipitation was substituted for charcoal-dextran separation. Urinary norepinephrine and epinephrine were analyzed by spectrophotofluorimetry using previously described techniques (52).

\footnotetext{
'The collaboration of Drs. Joseph Repice, Robert Baker, Susan S. Baker, Martin Hoffman, Martin Brecher, John Braico, Kathleen Braico, and Steven Commins was vital to the success of the study and to the care of these sick patients.

${ }^{2}$ Hydrating solution $(\mathrm{Na}=75 ; \mathrm{Cl}=50$; lactate $=25 \mathrm{mEq} /$ liter).

: $\mathrm{Na}=56 ; \mathrm{K}=25, \mathrm{Mg}=6 ; \mathrm{Cl}=50$; lactate $=25 ; \mathrm{H}_{2} \mathrm{PO}_{4}=12 \mathrm{mEg} /$ liter.

4 Same as Footnote 3 except $\mathrm{K}=40 ; \mathrm{H}_{2} \mathrm{PO}_{4}=27 \mathrm{mEq} /$ liter.
}

\section{RESULTS}

\section{CLINICAL INFORMATION}

Twenty patients were studied in 25 episodes of ketoacidosis. Table 1 summarizes the clinical data. There were 15 girls and 5 boys. Eleven girls (14 studies) and two boys were either pubescent or fully sexually mature; the other seven children (nine studies) were prepubertal. All had been followed in the Diabetic Clinic of Children's Hospital. The duration of ketonuria and of symptoms in most cases was less than $12 \mathrm{hr}$; in nine cases, less than $4 \mathrm{hr}$ before admission. In 13 cases, the last insulin dose had been given within $3 \mathrm{hr}$ before admission. None of the patients were comatose.

In 20 of 25 studies, the probable event which precipitated the ketoacidosis could be identified. In eight otherwise stable patients (cases 1, 8, 9, 12, 16, 19, 23, and 24), infection was the dominant factor. In six other studies (Cases 4, 6, 7, 13, 21, and 25), a combination of infection and emotional stress seemed to be present. Most of the infections were mild. The remaining six episodes of acute ketoacidosis appeared to be triggered by emotional and, on one occasion, physical stress.

\section{LABORATORY DATA}

The biochemical and hormone data in the 16 diabetic patients treated with the high dose insulin method were not significantly different from the nine who received "low dose" insulin therapy. The laboratory data from these two groups were combined for analysis and discussion.

Blood concentrations of glucose on admission ranged from 252 to $849 \mathrm{mg} / \mathrm{dl}$; in 22 cases, the values were less than $594 \mathrm{mg} / \mathrm{dl}$. There was no correlation between the glucose and $\mathrm{pH}$ values in individual patients. The highest blood glucose level, $849 \mathrm{mg} / \mathrm{dl}$, was seen in a patient whose blood $\mathrm{pH}$ was 7.36. In 10 cases, the glucose concentration fell by as much as $100 \mathrm{mg} / \mathrm{dl}$ before insulin administration, sometimes while glucose-containing solutions were being infused. In four cases, it rose steeply before fluid or insulin therapy. There was no consistent relationship between these changes in glucose concentrations and the timing of insulin therapy or the initial hormone data. Only three patients had bacterial infections for which they received antibiotic therapy (cases 16, 19, and 24).

Excessive urinary excretion of epinephrine was a striking hormonal abnormality observed in the majority of patients, particularly at the outset. Figure 1 shows the catecholamine excretion in the first collection period. Epinephrine excretion ranged from 0.225 to $8.40 \mu \mathrm{g} / \mathrm{M}^{2} / \mathrm{hr}$. In 20 of 23 cases, urinary epinephrine excretion in the first two periods was greater than 4 S.D., and in 10 of these, it was more than 10 S.D. above the normal mean (52). The pattern of epinephrine excretion throughout the 24-hr study period is shown in Figure 2. The magnitude and duration of epinephrine hypersecretion varied among the patients. In most cases, peak values were present on admission, and epinephrine excretion decreased gradually during the recovery from ketoacidosis. In 15 observations, the average time for the values to fall to within 2 S.D. of the normal mean was $14.5 \mathrm{hr}$ (range, 2 to $27 \mathrm{hr}$ ). In seven cases, the rate of epinephrine excretion exceeded 2 S.D. above normal throughout the entire observation period. In only three studies (Cases 12, 21, and 22) did epinephrine production remain within 2 S.D. of the mean for the entire period.

The total 24-hr excretion of epinephrine was more than 2 S.D. above the mean in 16 complete urine collections and greater than $8 \mathrm{~S}$.D. above the mean in five of 22 complete urine collections (Fig. 3). In six cases, the 24-hr output of epinephrine fell within the normal range even though three of these patients had increased amounts of epinephrine in the initial urine samples.

Norepinephrine excretion during the first collection period was elevated 2 S.D. above the mean in five patients (Fig. 1). The range of values for all participants was 0.32 to $15.85 \mu \mathrm{g} / \mathrm{M}^{2}$. Only one patient, on two occasions, excreted more than $5 \mu \mathrm{g} / \mathrm{M}^{2} / \mathrm{hr}$ (cases 15 and 20 ). The $24-\mathrm{hr}$ pattern of urinary norepinephrine excretion 
Table 1

\begin{tabular}{|c|c|c|c|c|c|c|c|c|c|c|c|}
\hline \multirow[b]{2}{*}{ Case No. } & \multirow[b]{2}{*}{ Sex } & \multirow{2}{*}{$\begin{array}{l}\text { Age at diag- } \\
\text { nosis of dia- } \\
\text { betes mellitus } \\
(\mathrm{yr})\end{array}$} & \multirow[b]{2}{*}{$\begin{array}{l}\text { Age at time of } \\
\text { study }(\mathrm{yr})\end{array}$} & \multirow[b]{2}{*}{$\begin{array}{l}\text { Interval since } \\
\text { last insulin } \\
\text { dose (hr) }\end{array}$} & \multirow[b]{2}{*}{$\begin{array}{l}\text { Dose of Insulin } \\
\quad \text { (units) }\end{array}$} & \multirow[b]{2}{*}{$\begin{array}{l}\text { Symptoms/ } \\
\text { ketonuria be- } \\
\text { fore admis- } \\
\text { sion (hr) }\end{array}$} & \multicolumn{3}{|c|}{ Admission laboratory data } & \multirow[b]{2}{*}{$\begin{array}{l}\text { No. of previ- } \\
\text { ous episodes of } \\
\text { ketoacidosis }\end{array}$} & \multirow[b]{2}{*}{$\begin{array}{l}\text { Apparent cause of acute epi- } \\
\text { sode of ketoacidosis }\end{array}$} \\
\hline & & & & & & & $\begin{array}{l}\text { Glucose } \\
\text { (mg/dl) }\end{array}$ & $\mathrm{pH}$ & $\begin{array}{c}\mathrm{Co}_{2} \\
\text { content } \\
\text { (meq/liter) }\end{array}$ & & \\
\hline 1 & $\mathbf{M}$ & $1 / 1 / 2$ & $4^{n / 12}$ & 3 & $12 U+10 R$ & 8 & 410 & 7.21 & 11.0 & 0 & Otitis media. \\
\hline 2 & $\mathrm{~F}$ & $10^{5 / 12}$ & $15 \% / 12$ & $71 / 2$ & $34 \mathrm{U}+16 \mathrm{~S}$ & 9 & 394 & $7.13 \mathrm{~A}$ & 6.5 & 5 & $\begin{array}{l}\text { Vomiting, } 7 \mathrm{hr} \text {. No identifiable } \\
\text { cause. }\end{array}$ \\
\hline 3 & $\mathbf{F}$ & $8 / 12$ & $13^{11 / 12}$ & $3 / 4$ & $26 U+8 R$ & 1 & 357 & $7.15 \mathrm{~V}$ & 10.2 & 4 & No apparent cause. \\
\hline 4 & $\mathbf{F}$ & $6 \% / 12$ & $14 y_{12}$ & $74 / 2$ & $34 U+6 R+24 S$ & 7 & 316 & $7.03 \mathrm{~A}$ & 6.5 & 12 & $\begin{array}{l}\text { Recurrent carbuncles, celluli- } \\
\text { tis, vomiting, emotional } \\
\text { stress. }\end{array}$ \\
\hline 5 & $\mathbf{F}$ & $89 / 12$ & $11 \% / 12$ & $2^{1 / 2}$ & $10 U+10 S$ & 5 & 345 & $7.37 \mathrm{~A}$ & 10 & 7 & No apparent cause. \\
\hline 6 & $\mathbf{F}$ & $19 / 12$ & 11.0 & 15 & $13 U+12 R$ & 15 & $849-977$ & $7.36 \mathrm{~A}$ & 14 & 5 & $\begin{array}{l}\text { Mild enteritis, emotional } \\
\text { stress. }\end{array}$ \\
\hline 7 & $\mathrm{~F}$ & $\begin{array}{l}\text { Same as case } \\
\quad 4\end{array}$ & $14 \% / 12$ & $<3$ & $6 R+34 U+24 S$ & 3 & 252 & 7.27 & 10 & 13 & $\begin{array}{l}\text { Possible Somogyi Syndrome, } \\
\text { also frequent skin infections, } \\
\text { slight URI (see case 4), emo- } \\
\text { tional stress. }\end{array}$ \\
\hline 8 & $\mathbf{F}$ & $119 / 12$ & $18 / 1,2$ & 8 & $22 U+8 R$ & 6 & 310 & $7.19 \mathrm{~V}$ & 9 & 1 & $\begin{array}{l}\text { Severe, primary herpes vulvo- } \\
\text { vaginitis. }\end{array}$ \\
\hline 9 & $\mathbf{M}$ & $11 / 12$ & $23 / 12$ & 4 & $5 U+4 S$ & 23 & 410 & $7.22 \mathrm{~V}$ & 10 & 0 & Acute gastroenteritis. \\
\hline 10 & $\mathbf{F}$ & $\begin{array}{l}\text { Same as case } \\
\quad 5\end{array}$ & 12.0 & 3 & $13 U+13 S$ & 3 & 577 & $\begin{array}{l}7.24 \mathrm{~A} \\
7.18 \mathrm{~V}\end{array}$ & $\begin{array}{l}4.3 \\
6.8\end{array}$ & 9 & $\begin{array}{l}\text { Vomiting, no identifiable } \\
\text { cause. }\end{array}$ \\
\hline 11 & $\mathbf{M}$ & $13 \frac{112}{12}$ & $20^{11 / 12}$ & $\begin{array}{r}7 \\
<3\end{array}$ & $\begin{array}{l}70 U+20 R \\
8 R\end{array}$ & 8 & 497 & $7.25 \mathrm{~A}$ & 13.3 & 12 & Physical and emotional stress. \\
\hline 12 & $\mathbf{F}$ & $711 \% 12$ & $177^{x / 12}$ & 24 & $42 U+22 R$ & 3 & 704 & 7.15 & 12 & 5 & Respiratory infection. \\
\hline 13 & $\mathrm{~F}$ & $9^{i / 12}$ & 17.0 & $71 / 2$ & $6 R+44 U+20 S$ & 3 & 465 & 7.09 & 5.5 & 7 & $\begin{array}{l}\text { Gastroenteritis, emotional } \\
\text { stress. }\end{array}$ \\
\hline 14 & $\mathbf{F}$ & 6.0 & $12^{110 / 12}$ & 27 & $28 U+16 S$ & 4 & 400 & $7.13 \mathrm{~A}$ & 12.9 & 12 & Emotional stress, vomiting. \\
\hline 15 & $\mathrm{~F}$ & $16^{2 / 12}$ & $175 / 12$ & 24 & $72 U+30 R$ & 3 & $496-717$ & $\begin{array}{l}7.03 \mathrm{~A} \\
6.96 \mathrm{~V}\end{array}$ & $\begin{array}{l}2.9 \\
6.5\end{array}$ & 8 & Emotional stress. \\
\hline 16 & $\mathbf{F}$ & $35 \%$ & $10^{1 / 12}$ & 2 & $24 \mathrm{PZI}+10 \mathrm{R}$ & 8 & 838 & $7.12 \mathrm{~A}$ & 6.5 & 1 & Acute pharyngitis. \\
\hline 17 & $\mathrm{~F}$ & $11 \% 11: 2$ & $16^{2 / 12}$ & $5 ?$ & $40 \mathrm{NPH}+16 \mathrm{R}$ & 5 & 420 & $7.08 \mathrm{~A}$ & 8 & 2 & No identifiable cause. \\
\hline 18 & $\mathrm{~F}$ & 3.0 & $6 \% 12$ & $21 / 2$ & $12 U+8 R$ & 3 & 336 & $7.30 \mathrm{~A}$ & 12.3 & 5 & Emotional stress. \\
\hline 19 & $\mathrm{~F}$ & 11.0 & $189 / 12$ & $1 / 2$ & $12 U+12 R$ & 4 & $454 ?$ or 481 & $7.03 \mathrm{~A}$ & 3.0 & 1 & $\begin{array}{l}\text { Severe vulvitis + carbuncles } \\
\text { and staphylococcus bacter- } \\
\text { emia. }\end{array}$ \\
\hline 20 & $\mathbf{F}$ & $\begin{array}{l}\text { Same as case } \\
\quad 15\end{array}$ & $17^{11 / 12}$ & $13 ?$ & $62 U+32 R$ & 6 & $408-622$ & $6.99 \mathrm{~A}$ & 2.1 & 10 & Emotional stress. \\
\hline 21 & $\mathbf{F}$ & $\begin{array}{l}\text { Same as case } \\
4\end{array}$ & $15^{11 / 12}$ & $11 / 2$ & $6 \mathrm{R}+32 \mathrm{U}+22 \mathrm{~L}$ & 9 & 594 & 7.26 & 13.5 & 16 & Emotional stress, nausea. \\
\hline 22 & $\mathbf{M}$ & $74_{12}$ & $13 \frac{5}{12}$ & $91 / 2$ & $36 U+8 R$ & 10 & 347 & $7.13 \mathrm{~V}$ & 14.3 & 7 & $\begin{array}{l}\text { Emotional lability, vomiting, } \\
\text { (7th of } 12 \text { admissions in } 13 \\
\text { mos.) }\end{array}$ \\
\hline 23 & $\mathbf{M}$ & $51 \% 12$ & $6^{9 / 12}$ & $2^{1 / 2}$ & $51 / 2 U+3 S$ & 10 & 388 & $7.31 \mathrm{~V}$ & 17 & $\mathbf{0}$ & Viral URI with vomiting. \\
\hline 24 & $F$ & $11^{3 / 12}$ & $14 \% / 12$ & $23 / 4$ & $30 U+6 R$ & 14 & 477 & $7.04 \mathrm{~V}$ & 7 & 0 & $\begin{array}{l}\text { Fever, pharyngitis, and vagin- } \\
\text { itis. }\end{array}$ \\
\hline 25 & $\mathbf{F}$ & $\begin{array}{l}\text { Same as case } \\
\quad 18\end{array}$ & $75 / 12$ & 2 & $13 U+13 R$ & 3 & 346 & $7.21 \mathrm{~V}$ & 12 & 11 & $\begin{array}{l}\text { URI with vomiting, emotional } \\
\text { stress. }\end{array}$ \\
\hline
\end{tabular}




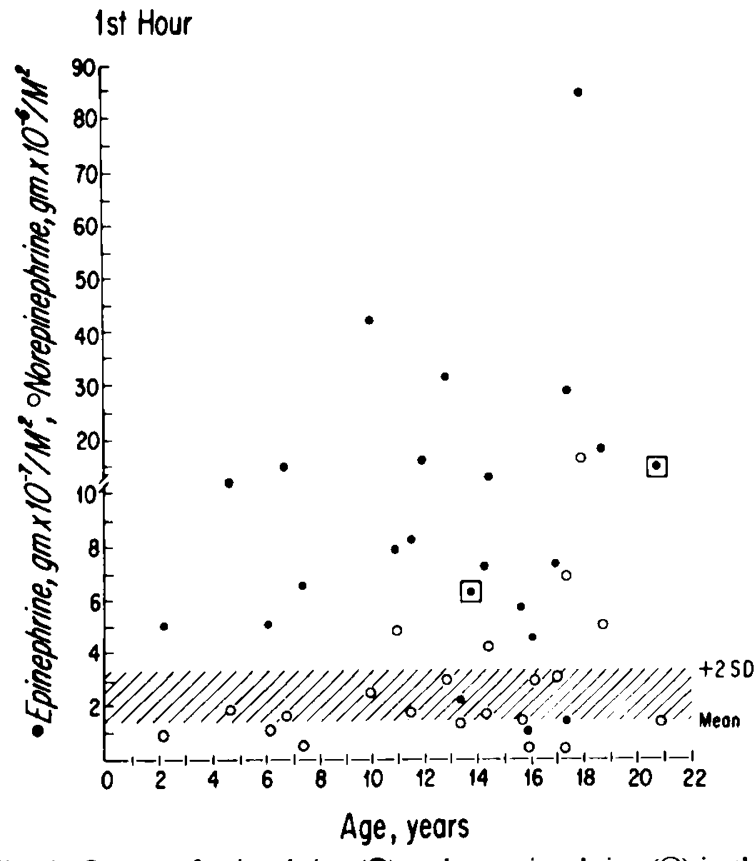

Fig. 1. Output of epinephrine $(O)$ and norepinephrine $(O)$ in the first urine collection, expressed as excretion rate per $\mathbf{M}^{2} / \mathrm{hr}$. Data are displayed according to the patients' ages along the abscissa. The mean and + 2 S.D. range of normal children (50) is shown by the cross-hatched area. In 2 cases $(\square)$, the first urine specimen was lost, and the values shown were obtained in the second collection period. The catecholamine output is along the ordinate; norepinephrine and epinephrine scales differ by a factor of 10

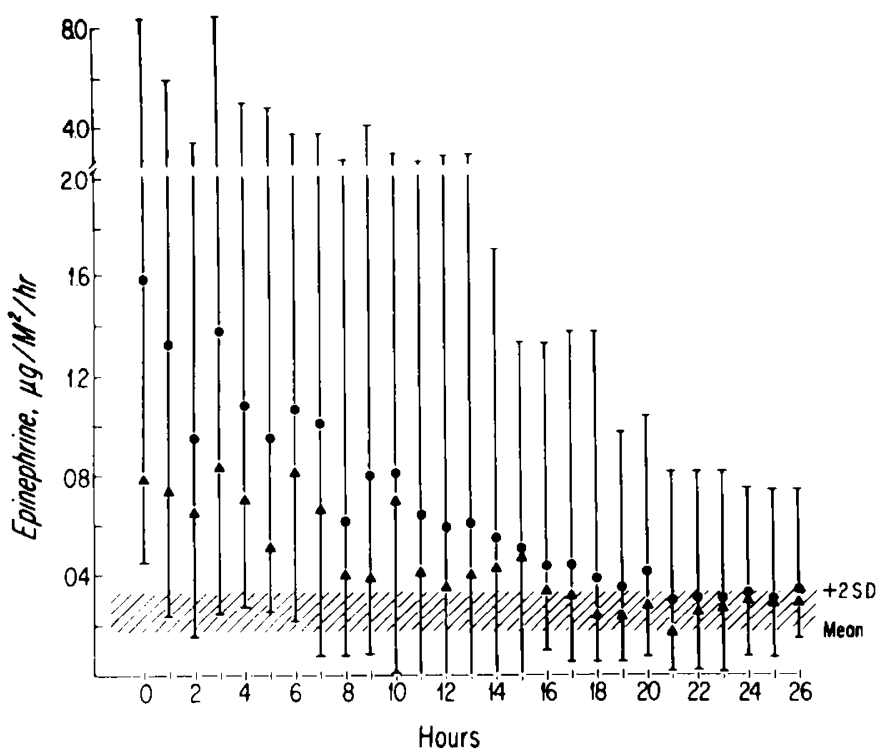

Fig. 2. Pattern of hourly excretion rate of epinephrine in $\mu \mathrm{g} / \mathrm{M}^{2} /$ hour for the whole group. Data include the range, the mean (๑), and the median (A) displayed for the hours of the study along the abscissa. The epinephrine scale is along the ordinate. The mean + S.D. range for normal children is shown by the cross-hatched area (50). The mean and median values did not vary significantly during the first $8 \mathrm{hr}$. The mean and median values are in the normal range during the last $6 \mathrm{hr}$ although seven patients still excreted epinephrine at a rate above 2 S.D. of the normal mean. Of 337 timed urine specimens analyzed, 30 contained more than $2.0 \mu \mathrm{g}$ of epinephrine per $\mathrm{M}^{2}$ per hour (normal, 0.1 to $0.2 \mu \mathrm{g} / \mathrm{M}^{2} / \mathrm{hr}$ ).

was different from that of epinephrine. The rate of output of hormone remained fairly constant during the study except in five children in whom it increased. The total output of norepinephrine in $24 \mathrm{hr}$ was normal in 19 studies. In three cases, it exceeded 100 $\mu \mathrm{g} / \mathrm{M}^{2} / 24 \mathrm{hr}$ (Fig. 3).

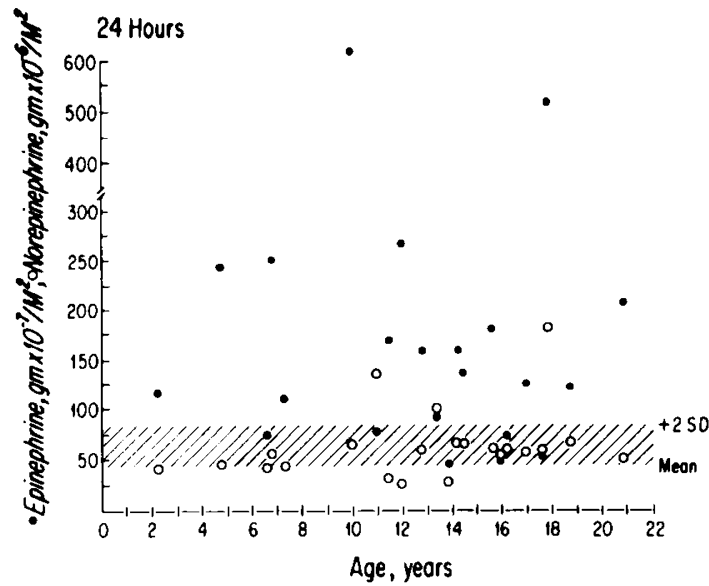

Fig. 3. Total excretion of epinephrine and norepinephrine in $24 \mathrm{hr}$ by individual patients. Code as in Figure 1. Epinephrine output per $24 \mathrm{hr}$ was more than 2 S.D. above the mean in 16 patients. Norepinephrine excretion per $24 \mathrm{hr}$ was greater than 2 S.D. above the mean in three cases.

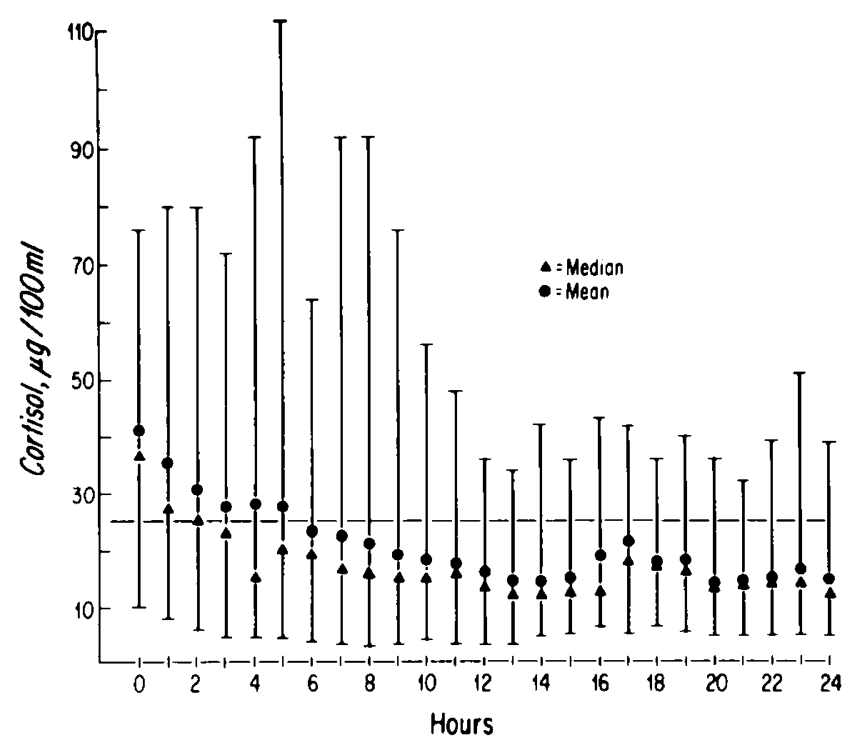

Fig. 4. Hourly concentrations of plasma cortisol in $\mu \mathrm{g} / \mathrm{dl}$ are displayed for the 25 studies. Data include the range, the mean $(\theta)$, and the median $(\Delta)$. Peak values are present at the outset and gradually return to the normal range during the recovery period. An occasional patient had persistent hypersecretion of cortisol throughout the entire study period. The line depicts the upper limit of the diurnal range $(25 \mu \mathrm{g} / \mathrm{dl})$.

Cortisol hypersecretion was another prominent hormonal abnormality. In the majority of the patients, continuous hypercortisolemia, characteristic of a stress response, replaced the usual diurnal rhythm. Figure 4 shows the range, the mean, and the median values of plasma corticoid concentration in the 25 cases for each hour. The mean plasma corticoid concentration on admission was $38 \mu \mathrm{g} / \mathrm{dl}$ (range, 10 to $76 \mu \mathrm{g} / \mathrm{dl}$ ); in 17 cases, it was above $25 \mu \mathrm{g} / \mathrm{dl}$. Of the 25 initial cortisol values, 24 were elevated relative to the normal diurnal concentration. Hypersecretion of cortisol continued in most of the children for the first 6 to $8 \mathrm{hr}$ and then gradually subsided. However, in a few patients, it persisted throughout most of the study. The three most severely ill patients had the highest corticoid levels for the longest time; one of these cases is illustrated in Figure 5. The 24-hr plasma corticoid pattern was similar to that of epinephrine with the peak values occurring in the early hours.

The growth hormone levels at the time of admission ranged from 1.6 to $39.6 \mathrm{ng} / \mathrm{ml}$, and only seven patients had values of 20 $\mathrm{ng} / \mathrm{ml}$ or higher. There was a significant difference $(0.02<P<$ 


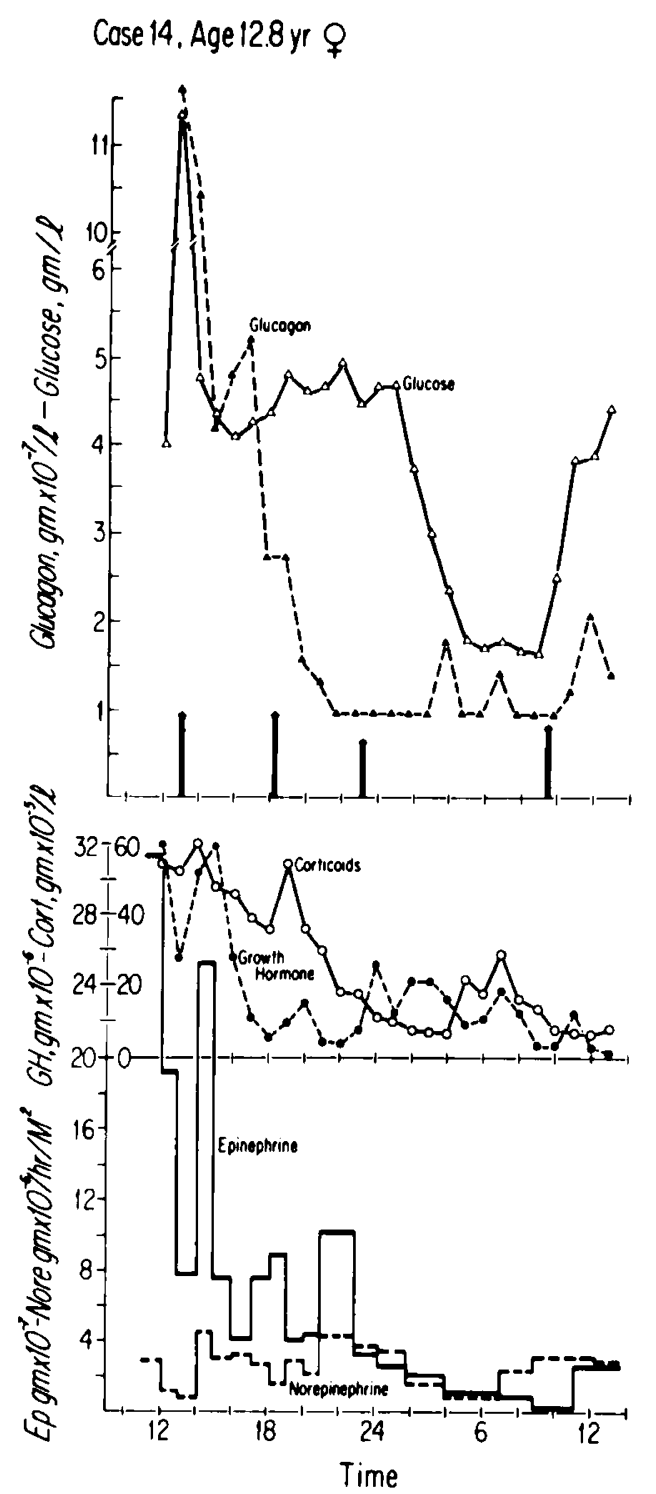

Fig. 5. Plasma concentrations of glucose, corticoids, and growth hormone and excretion rates of catecholamines in case 14. Clock time is given along the abscissa. The inner scale in the center panel refers to cortisol and growth hormone $(\mu \mathrm{g} / \mathrm{dl}$ and $\mathrm{ng} / \mathrm{ml}$, respectively). In the iwo lower panels, the outer scale refers to the urinary catecholamine output per $\mathbf{M}^{2}$ per hr. Norepinephrine and epinephrine scales differ by a factor of 10 , corresponding to the usual average ratio of these two catecholamines in urine. The "normal" excretion rate for both would be between I and 2 on this scale. Insulin doses are indicated by the height of the arrows. Note peaks of growth hormone following every injection of insulin. Extraordinary elevation of epinephrine was present at the outset and persisted for the first $12 \mathrm{hr}$ but returned to normal by the $16 \mathrm{th} \mathrm{hr}$.

0.05 ) between the initial growth hormone levels of the 13 patients who had received insulin at home within $3 \mathrm{hr}$ before arrival (mean, > 17.3; median, $20 \mathrm{ng} / \mathrm{ml}$ ) and the levels of those who had not had insulin recently (mean, 9.8 ; median, $6.2 \mathrm{ng} / \mathrm{ml}$ ). After administration of insulin in the hospital, growth hormone concentrations rose in 19 of 25 cases and reached a peak 1 to $2 \frac{1}{2} \mathrm{hr}$ after the injection (Fig. 6). In all cases, these peaks ranged from 30 to $160 \mathrm{ng} / \mathrm{ml}$ (Fig. 6). The highest concentrations of growth hormone were present in the $4 \mathrm{hr}$ after the first insulin injection and then fell to below $8 \mathrm{ng} / \mathrm{ml}$, but there were intermittent subsequent spikes which seemed related to insulin injections, sleep, or unknown causes.

Hyperglucagonemia (values ranging from 250 to $1250 \mathrm{pg} / \mathrm{ml}$ ) was present on admission in 11 cases; four of these had levels

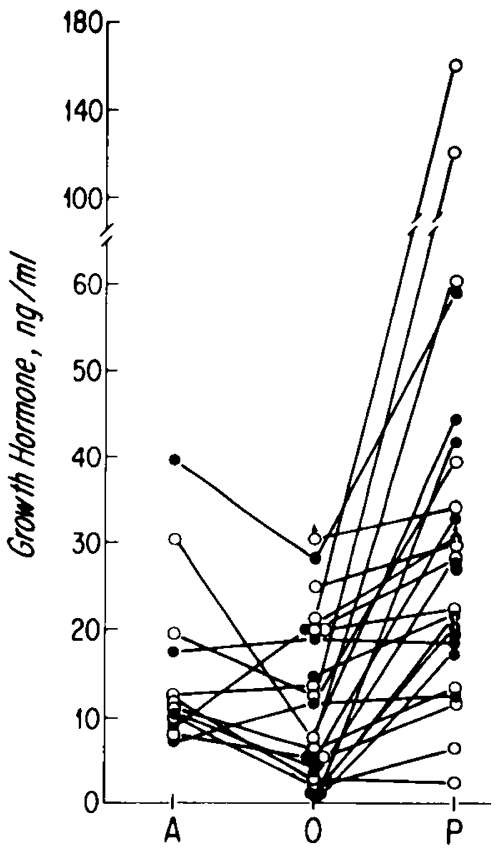

Fig. 6. Growth hormone concentrations in plasma in individual patients. $A$, at the time of admission (in the cases in which two or more samples were obtained before the first insulin injection); $O$, immediately before the first insulin injection; $P$, peak observed at any time during the first $3 \mathrm{hr}$ after this injection. $O$, patients who had received insulin at home within 3 to $31 / 2 \mathrm{hr}$ before admission; 9 , patients who received their last insulin dose more than $31 / 2 \mathrm{hr}$ before admission. (Because in several cases the growth hormone concentration exceeded the upper limit of the analytical method and insufficient serum was available for repeat on a diluted specimen, four of the values, indicated here by arrows, are only minimal estimates.)

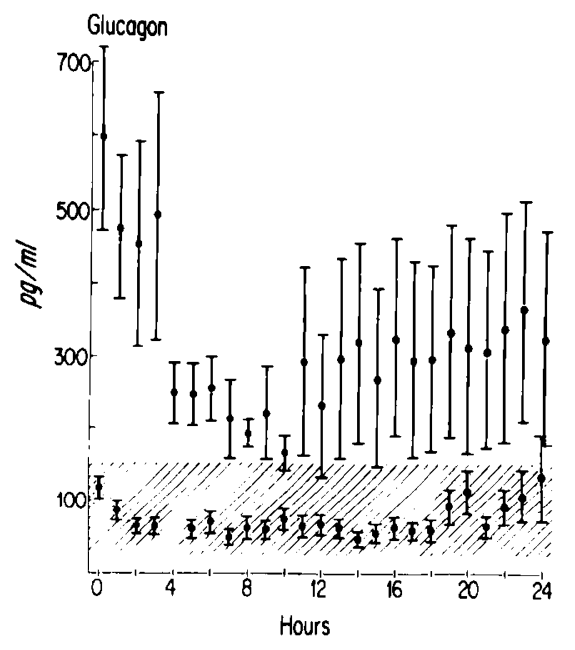

Fig. 7. Plasma glucagon concentrations $(\mathrm{pg} / \mathrm{ml} \pm \mathrm{S}$.E.) are shown for a group $(n=11)$ of ketoacidotic patients whose values were less than 200 $\mathrm{pg} / \mathrm{ml}$ at the outset and for most of the study. This group falls into the "normal range" shown by cross-hatched area. A second group $(n=11)$ had high plasma glucagon values $(250$ to $1250 \mathrm{p} / \mathrm{ml})$ at the outset and throughout the study. The large S.E. illustrates the marked variability among these patients.

between 900 and $1250 \mathrm{pg} / \mathrm{ml}$. In 11 other patients, the initial concentrations were below $200 \mathrm{pg} / \mathrm{ml}$ and remained so for most of the study. The glucagon values in these two groups are shown in Figure 7. Most of the very high concentrations of glucagon were observed during the first hr or two after admission, and usually, they were transient. However, throughout the study period, several patterns of glucagon secretion were observed which 
account for the very large standard errors of the mean seen in Figure 7.

There was no correlation between the severity of the acidosis or hyperglycemia seen in these patients on admission and the first plasma level of cortisol, growth hormone, or glucagon. Likewise, the first urinary output of epinephrine or norepinephrine did not correlate with the degree of ketoacidosis.

\section{DISCUSSION}

Diabetic ketoacidosis is usually ascribed to an absolute (13) or relative deficiency of insulin (38). Absolute deficiency can be ruled out in most of the cases in this series because all but two patients had received their usual doses of short- and long-acting insulin on the day of admission one-half of them within $3 \mathrm{hr}$ before arrival at the hospital. The rapid onset of ketoacidosis in these patients suggested that stress triggered the release of large amounts of counterregulatory hormones which overwhelmed the action of insulin. This hypothesis is supported by a recent study involving six insulin-treated diabetics given intravenous pseudomonas polysaccharide, a potent pyrogen. Malaise, chills, and fever were followed rapidly by increases in plasma concentrations of growth hormone, catecholamines, and cortisol which preceded by $30 \mathrm{~min}$ elevations in plasma ketones. However, acidosis per se was not reported (39).

Hyperexcretion of epinephrine was a frequent and striking phenomenon in our patients ( 20 of 23 initial observations). Epinephrine output was much more elevated than norepinephrine. However, urine measurements may not be representative of the total quantity of norepinephrine produced because the primary mechanism of inactivation of this catecholamine is reuptake into the storage granules and only small amounts are released into the circulation and subsequently excreted into the urine (29). Elevated plasma levels of norepinephrine have been reported in patients with ketoacidosis $(11,53)$.

The finding of peak epinephrine output close to the onset, followed by gradual return to normal baseline values during the recovery period, suggests that the catecholamine abnormality was provoked by some stressful stimulus. In 1950, Hinkle et al. (25) reported that both diabetic and nondiabetic humans have a rise in blood ketones within $2 \mathrm{hr}$ after psychologic stress, but the ketone levels were higher in the diabetics. Subsequently, Baker et al. (2) reported that excessive epinephrine production, hyperglycemia, and elevated plasma free fatty aid levels occurred after a stressful psychiatric interview with an adolescent diabetic girl who had had repeated bouts of acute ketoacidosis precipitated by emotional conflict. In addition, Christensen et al. (10) observed elevated plasma concentrations of epinephrine and norepinephrine in diabetics during ketoacidosis. After treatment with insulin and correction of acidosis, the catecholamine values returned to normal. There is no evidence of a primary overproduction of catecholamines in patients with diabetes mellitus.

The catecholamines, particularly epinephrine, are the most potent of the lipolytic hormones. Furthermore, both epinephrine and norepinephrine stimulate glucagon secretion which enhances the capacity of the liver to convert fatty acids into ketone bodies $(19,28)$. Thus, the catecholamines and glucagon combine to promote both lipolysis and ketogenesis as well as glycogenolysis and hyperglycemia.

The role of glucagon in diabetes mellitus has been extensively evaluated. Muiller et al. (31) found that plasma glucagon levels in insulin-deficient acidotic patients correlated with blood glucose and with the duration of insulin therapy required to reduce ketone bodies in serum. They concluded that increased circulating glucagon contributed to the severity of the metabolic derangement and hypothesized that primary abnormalities of both the alpha and beta cells were present in patients with diabetes mellitus (51). This conclusion now must be modified in view of reports which indicate that insulin deficiency is necessary for glucagon to cause marked hyperglycemia $(3,44,46)$.
In our patients, the initial plasma concentrations of glucagon did not correlate with the degree of epinephrine overproduction, and elevated plasma glucagon levels were noted less frequently. In fact, glucagon concentrations at the outset were below $200 \mathrm{pg} /$ $\mathrm{ml}$ in 11 patients. In several additional individuals, glucagon levels fell rapidly after admission even though increased epinephrine production continued. Although glucagon has been implicated as an important hormone in catabolic illness (49), low levels of glucagon were observed in our single patient with a severe bacterial infection (case 19). The emotionally stressed patient who excreted the largest amount of catecholamines had no significant hyperglucagonemia (cases 15 and 20 ).

Hypercortisolemia in the early phase of acute ketoacidosis was as impressive as the abnormality observed in catecholamine production by our patients ( 24 of 25 initial plasma levels). Increased secretion of cortisol in children with diabetic ketoacidosis has been described previously, but its relationship to the other counterregulatory hormones was not evaluated simultaneously $(18,47)$. In a large proportion of cases, high corticoid concentrations persisted for 6 to $12 \mathrm{hr}$ whereas in a smaller group, it lasted for longer periods. Cortisol is known to promote gluconeogenesis which may contribute to the hyperglycemia seen in diabetic ketoacidosis. Studies suggest that glucocorticoids also enhance the lipolytic action of the counterregulatory hormones and possibly possess primary lipolytic activity $(14,33,37,42)$.

In contrast to the marked elevations of corticoid and catecholamines, growth hormone levels were not maximal at the time of admission (only seven had values $>20 \mathrm{ng} / \mathrm{ml}$ ) but peaked after the first injections of insulin. After insulin administration, 17 patients had values which ranged from 20 to $160 \mathrm{ng} / \mathrm{ml}$. Augmented growth hormone secretion due to stress has been reported in healthy subjects $(5,22,24,41)$ and is more pronounced in diabetic $(23,30)$ patients. Spikes of growth hormone have been described after insulin administration regardless of blood glucose concentrations $(12,16,45)$.

Determinations of the major counterregulatory hormones at onset of ketoacidosis showed that 21 of 22 patients had increased production of at least three of the stress hormones. Although there was variability in the severity and duration of the hormonal responses, extraordinary increases in catecholamine and cortisol production were observed in almost every patient whereas glucagon and growth hormone concentrations were high in about onehalf of the group. Increased lipolysis as well as conversion of liberated free fatty acids to ketone bodies via hepatic ketogenesis are prerequisites to ketoacidosis. The lipolytic effects of the catecholamines, growth hormone, glucagon, and cortisol have been documented, but their influence on ketogenesis is less well understood. The work of McGarry and Foster (28) indicates that glucagon is essential for augmentation of hepatic ketogenesis because of its ability to activate the carnitine acyl transferase system which transports fatty acid residues into mitochondria for oxidation to ketone bodies. The occurrence of acute ketoacidosis without hyperglucagonemia in some of our patients and the development of ketonemia in pancreatectomized humans (3) suggests that other stress hormones besides glucagon may enhance hepatic ketogenesis and lead to ketoacidosis.

A variety of stresses in humans provoke catecholamine, cortisol, glucagon, and growth hormone release, and the pattern of response is highly individualized $(5,9,17,20,24,26,34,35,41,55)$. The intensity and character of each response may depend on conditioning factors, including genetic disposition and past experiences $(17,26,43)$. Inasmuch as all these hormones overwhelm the action of insulin at one or more of its target tissue(s), it is likely that the usual dose of insulin in diabetic patients is insufficient to offset the effects of these counterregulatory hormones. Thus, ketoacidosis ensues (38).

An important question concerns the difference in susceptibility to ketoacidosis among patients with juvenile onset diabetes mellitus. The majority of diabetic children seldom, if ever, require hospitalization although a minority have occasional or repeated 
bouts of acute ketoacidosis despite competent medical care. It is indeed remarkable that in a 20 -year review of hospitalizations of nearly 600 diabetic children in one institution, over $60 \%$ never required admission after the initial hospitalization which established the diagnosis, whereas $12 \%$ of patients accounted for all the cases with more than two admissions (6). One cannot ascertain from available data whether those who are not prone to acute ketoacidosis have different stress hormone patterns or whether they possess residual beta cell function which provides stability of metabolic control. In two recent studies, residual beta cell function was found in some diabetic chidlren months to years after onset of disease $(4,27)$. Further studies of endogenous insulin reserves and stress hormone production in these two groups of juvenile onset diabetics are needed to improve our understanding of the factors which place diabetic children at risk for developing acute ketoacidosis.

\section{REFERENCES AND NOTES}

1. Alberti, K. G. M. M., Christensen, N. J., Iversen, J., and Orskov, H.: Role of glucagon and other hormones in development of diabetic ketoacidosis. Lancet, l: 1307 (1975)

2. Baker, L., Barcai, A., Kaye, R., and Haque, N.: Beta-adrenergic blockade and juvenile diabetes: Acute studies and long-term therapeutic trial. J. Pediatr., 75: 19 (1969)

3. Barnes, A. J., Bloom, S. R., Alberti, K. G. M. M., Smythe, P., Alford. F. P., and Chisholm, D. J.: Ketoacidosis in pancreatectomized man. N. Engl. J. Med.. 296: 1250 (1977).

4. Binder, $C$., and Faber, $O$. K.: Residual beta cell function and its metabolic consequences. Diabetes, 27 (Suppl. I): 226, (1978)

5. Brown, G. M., and Reichlin, S.: Psychologic and neural regulation of growth hormone secretion. Psychosom. Med., 34: 45 (1972).

6. Bruck. E.: (unpublished observations).

7. Bruck. E., MacGillivray, M. H., and Voorhess, M. L.: Stress Hormones in Diabetic Ketoacidosis. Pediatr. Res. (Abstract), 11: 423 (1977).

8. Bruck. E., MacGillivray, M. H., and Voorhess, M. L.: Hormonal balance during acute ketoacidosis in children with previously controlled diabetes mellitus. In: Laron: Medical Aspects of Balance of Diabetes in Juveniles. Pediatric and Adolescent Endocrinology. Vol. 2, pp. 207-219 (Karger, Basel, 1977).

9. Christensen, N. J.: Abnormally high plasma catecholamines at rest and during exercise in ketotic juvenile diabetics. Scand. J. Clin. Lab. Invest., 26: 343 (1970).

10. Christensen, N. J.: Plasms norepinephrine and epinephrine in untreated diabetics, during fasting and after insulin administration. Diabetes, 23: I (1974).

11. Christensen, N. J.: Catecholamines and diabetes mellitus. Diabetologia, 16: 211 (1979).

12. Cryer, P. E., and Daughaday, W. H.: Diabetic ketosis. Serial plasma growth hormone concentrations during therapy. Diabetes, 19: 519 (1970).

13. Cryer, P. E.: Diagnostic Endocrinology. Ed. 2, p. 185 (Oxford University Press, New York, 1979).

14. Fain, J. N., and Czech. M. P.: Glucocorticoid effects on lipid mobilization and adipose tissue metabolism. In: H. Blaschko G. Sayers, A. D. Smith: Handbook of Physiology VI Adrenal Gland. (American Physiology Society, Washington D. C., 1975)

15. Faloona, G. R.. and Unger, R. H.: Glucagon. In: B. M. Jaffe, H. R. Behrman: Methods of Hormone Radioimmunoassay. p. 317 (Academic Press, Inc., New York, 1974).

16. Fatourechi, V.. Molnar, G. D., Service, F. J., Ackerman, E., Rosevear, J. W.. Moxness, K. E., and Taylor, W. F.: Growth hormone and glucose interrelationships in diabetes: Studies with insulin infusion during continuous blood glucose analysis. J. Clin. Endocrinol. Metab., 29: 319 (1969).

17. Frankenhaeuser, M., and Johansson, G.: Behavior and catecholamines in children. Chap. II. In: L. Levi: Society, Stress and Diseases, Vol. 2, pp. 118-126 (Oxford University Press, New York. 1975).

18. Garces, L. Y.. Kenny, F. M., and Drash, A.: Cortisol secretion rate in acidotic and non-acidotic juvenile diabetes mellitus. J. Pediatr., 74: 517 (1969)

19. Gerich. J. E.. Lorenzi. M.. Tsalikian, E., and Karam. J. H.: Studies on the mechanism of epinephrine-induced hyperglycemia in man. Evidence for participation of pancreatic glucagon secretion. Diabetes, 25: 65 (1976).

20. Greene. W. A.. Conron, G., Schalch. D. S., and Schreiner, B. F.: Psychologic correlates of growth hormone and adrenal secretory responses of patients undergoing cardiac catheterization. Psychosom. Med., 32: 599 (1970).

21. Greenwood, F. G., Hunter, W. M., and Glover, J. S.: The preparation of $I^{1.11}$ labeled human growth hormone of high specifc radioactivity. Biochem. J., 89. 114 (1963).

22. Greenwood, F, $\dot{C}$.. and Landon. J.: Growth hormone secretion in response to stress in man. Nature (Lond.), 210: 540 (1966).

23. Hansen, A. P.: Abnormal serum growth hormone response to exercise in juvenile diabetics. J. Clin. Invest.. 49: 1467 (1970).

24. Hanssen. K. F., and Asfeldt. V. H.: Human growth hormone secretion during major surgical stress and the influence of pre-treatment with dexamethasone. Horm. Metab. Res., 4: 57 (1972)

25. Hinkle, L. E., Jr., Conger, G. B., and Wolf, S.: Studies on diabetes mellitus: the relation of stressful life situations to the concentration of ketone bodies in the blood of diabetic and non-diabetic humans. J. Clin. Invest., 29: 754 (1950).

26. Kety, S. S.: Catecholamines in neuropsychiatric states. Pharmacol. Rev., 18: 787 (1966).

27. Ludvigsson, J., and Heding, L. G.: Beta cell function in children with diabetes. Diabetes 27 (Suppl. 1): 230 (1978).

28. McGarry, J. D., and Foster, D. W.: Ketogenesis and its regulation. Am. J. Med. 61: 9 (1976)

29. Molinoff, P. B., and Axelrod, J.: Biochemistry of catecholamines. Ann. Rev. Biochem., 40: 465 (1971).

30. Molnar, G. D., Taylor, W. F., Langworthy, A., and Fatourechi, V.: Diurnal growth hormone and glucose abnormalities in unstable diabetics: Studies of ambulatory-fed subjects during continuous blood glucose analysis. J. Clin Endocrinol. Metab., 34: 837 (1972).

31. Müller. W. A., Faloona, G. R., and Unger, R. H.: Hyperglucagonemia in diabetic keto-acidosis. Its prevalence and significance. Am. J. Med., 54: 52 (1973).

32. Murphy. B. E. P.: Some studies of the protein binding of steroids and their applicaton to the routine micro and ultra micro measurement of various steroids in body fluids by competitive protein binding radioimmunoassay. $\mathrm{J}$. Clin. Endocrinol. Metab., 27: 973 (1967).

33. Nayak, R. V., Feldman. E. B., and Carter, A. C.: Adipokinetic effect of intravenous cortisol in human subjects. Proc. Soc. Exp. Med., 8: 682 (1962).

34. Pátkai, P.: Catecholamine excretion in pleasant and unpleasant situations. Acta Psychol., 35: 352 (1971)

35. Rocha, D. M., Santeusanio, F., Faloona, G. R., and Unger, R. H.: Abnorma pancreatic alpha-cell function in bacterial infections. N. Engl. J. Med., 288 700 (1973).

36. Sacks, H. S., Shahshahani, M., Kitabchi, A. E., Fisher, J. N., and Young, R. T Similar responsiveness of diabetic ketoacidosis to low-dose insulin by intramuscular injection and albumin-free infusion. Ann. Intern. Med., 90: 36 (1979).

37. Schade, D. S., and Eaton, R. P.: The modulationof plasma ketone body concentration by endogenous cortisol in diabetic man. Clin. Res., 24: 626 A (1976).

38. Schade. D. S., and Eaton. R. P.: The controversy concerning counterregulatory hormone secretion. A hypothesis for the prevention of diabetic ketoacidosis Diabetes, 26: 596 (1977)

39. Schade, D. S., and Eaton, R. P.: The temporal relationship between endogenously secreted stress hormones and metabolic decompensation in diabetic man. $J$. Clin. Endocrinol. Metab., 50: 131 (1980).

40. Schalch. D. S., and Parker, M. L.: A sensitive double antibody immunoassay for human growth hormone in plasma. Nature (Lond.). 203: 1141 (1964).

41. Schalch, D. S.: The influence of physical stress and exercise on growth hormone and insulin secretion in man. J. Lab. Clin. Med., 69: 256 (1967).

42. Scow, R. O., Chernick, S. S., and Guarco, B. A.: Ketogenic action of pituitary and adrenal hormones in pancreatectomized rats. Diabetes, $8: 132$ (1959).

43. Selye, H.: Stress Without Distress. pp. 41-47 (J. B. Lippincott Co., Philadelphia, 1974).

44. Sherwin. R. S., Fisher, M.. Hendler, R., and Felig, P.: Hyperglucagonemia and blood glucose regulation in normal, obese and diabetic subjects. N. Engl. J. Med., 294: 455 (1976).

45. Sönksen. P. H., Tompkins, C. V., Srivastava, M. C., and Nabarro, J. D. N. Growth hormone and cortisol responses to insulin infusion in patients with diabetes mellitus. Lancet, 2: 155 (1972).

46. Sperling, M. A.. Aleck, K.. and Voina, S.: Suppressibility of glucagon secretion by glucose in juvenile diabetes. J. Pediatr., 90: 543 (1977).

47. Sperling, M. A., Bacon, G.. Kenny, F. M., and Drash, A. L.: Cortisol secretion in acidotic and non-acidotic diabetes mellitus. Am. J. Dis. Child., 124: 690 (1972).

48. Unger. R. H.: High growth hormone levels in diabetic keto-acidosis. A possible cause of insulin resistance. J. Am. Med. Assoc., 191: 945 (1964).

49. Unger, R. H.: Glucagon and the insulin:glucagon ratio in diabetes and other catabolic illnesses. Diabetes, 20: 834 (1971).

50. Unger, R. H., Aguilar-Parada, E., Müller, W. A., and Eisentraut, A. M.: Studies on pancreatic alpha cell function in normal and diabetic subjects. J. Clin Invest.. 49: 837 (1970)

51. Unger, R. H., and Orci, L.: The essential role of glucagon in the pathogenesis of diabetes mellitus. Lancet, 1: 14 (1975).

52. Voorhess, M. L.: Urinary catecholamine excretion by healthy children: I. Daily excretion of dopamine, norepinephrine, epinephrine and 3-methoxy-4-hydroxy-mandelic acid. Pediatrics, 39: 252 (1967).

53. Waldhäusl, W., Kleinberger, G., Korn, A., Dudczak, R., Bratusch-Marrain, P. and Nowotny, P.: Severe hyperglycemia: effects of rehydration on endocrine derangements and blood glucose concentration. Diabetes, 28: 577 (1979).

54. Werner, H., Rey, H. -G., and Wielinger, H.: Über die Eigenschaften eines neuen Chromogens fuir die Blutzuckerbestimmung nach der GOD-POD-Methode. Annal. Chem., 252: 224 (1970).

55. Wolfe, R. R., Durkot, M. J., Allsop. J. R., and Burke, J. F.: Glucose metabolism in severely burned patients. Metabolism, 28: 1031 (1979).

56. Part of this material was presented at the Third International Beilinson Symposium on the Balance of Diabetes in Juveniles in Tel Aviv, Israel in May, 1975 (8). A preliminary report entitled "Stress Hormones in Diabetic Ketoacidosis" was also presented at the Annual Meeting of The American Pediatric Society and The Society for Pediatric Research in San Francisco, California, April 25 29, 1977 (7).

57. The authors are deeply grateful to the Staff of the Clinical Research Center, to the technical personnel of the Endocrinology Laboratory and to our secretary. $M$. Link for their generous support of this project.

58. Requests for reprints should be addressed to: Dr. M. H. MacGillivray, Children's 
Hospital of Buffalo, 219 Bryant Street, Buffalo, NY 14222 (USA).

59. This research was supported by Grant RR 628 from the General Clinical Research Centers Program of the Division of Research Resources, National Institutes of Health; by Grant AM 17879 from the Department of Health. Education. and Welfare; and by Grant RR 05493 from the Biomedical Re-

Copyright $(1981$ International Pediatric Research Foundation, Inc. $0031-3998 / 81 / 1502-0099502.00 / 0$ search Support Grant Program. Division of Research Resources, National Institutes of Health. Purified hormones were generously provided by the National Pituitary Agency for many of the radioimmunoassay procedures. 60. Received for publication March 7, 1980. 61. Accepted for publication May 19, 1980.

Prinsed in U.S.A.

\section{LABORATORY DESIGN SEMINAR}

The First Southeastern Regional Laboratory Design Seminar will be held in Atlanta, Georgia, March 25-27, 1981.

This Seminar will cover the planning process, laboratory ventilation, energy conservation, utility requirements, laboratory furniture selection, biohazard and carcinogen control, building technology, and design innovations that can provide maximum, adaptability and optimum performance. Laboratory tours will be available.

Further information and registration forms can be obtained from Normal V. Steere \& Associates, Inc., 140 Melbourne Ave., S.E., Minneapolis, Minnesota 55414. Phone: 612-378-2711.

Registration fee is $\$ 400$, which includes course material and luncheons.

\section{ANNOUNCEMENT}

The annual meeting of the American Society of Pediatric Nephrology will be held at the Hilton Hotel in San Francisco, California, on Tuesday evening, April 28, 1981. This year the symposium will be entitled, "State of the Nephron: The Pediatric Nephrologist View." For further information, please contact Dr. Russel Chesney, Secretary-Treasurer, American Society of Pediatric Nephrology, University of Wisconsin Clinical Sciences Center, 600 Highland Avenue, H4/452, Madison, Wisconsin 53792. 